\title{
Quantitative Analysis of Orphan Nuclear Receptors in Insulin-Resistant C2C12 Skeletal Muscle Cells
}

\section{Chew GS ${ }^{1 \#, ~ G a w n e d ~} M^{1}$, Molina $E^{1}$ and Myers SA*\#}

${ }^{1}$ School of Science and Engineering, Federation University, Australia

${ }^{2}$ School of Health Sciences, University of Tasmania, Australia

\#These authors contributed equally to this work

\begin{abstract}
Orphan nuclear receptors (ONR) are members of the nuclear receptor (NR) super family of transcription factors that have been known to play a major role in lipid and glucose metabolism in skeletal muscle. Recently, pharmacological evidence supports the view that stimulation of NR alleviates Type 2 Diabetes (T2D). However the ligands and physiological functions of ONRs still remain unknown. To date, no systematic studies have been carried out to screen for ONRs expressed in insulin resistant skeletal muscle cells. Therefore, in this study, we have established a model for insulin resistance (IR) by treating $\mathrm{C} 2 \mathrm{C} 12$ skeletal muscle cells with insulin (10nM) for 48 hours. Western Blot analysis of phosphorylated AKT confirmed IR. By quantitative PCR, we identified that a number of the ONRs respond significantly during the progression of cellular insulin resistance which included Couptf1, Coup-tf2, Ppar $\beta$, NR4As, Reverba, and Rora, some of which have been associated with fatty acid oxidation regulation and glucose homeostasis and therefore could play a role in the aetiology of this disorder. Highlighted were observed increased mRNA expression levels of other ONRs in insulin resistant $\mathrm{C} 2 \mathrm{C} 12$ skeletal muscle cells, indicated that these ONRs could potentially play a pivotal regulatory role of insulin secretion in lipid metabolism. Taken together, this study has successfully contributed to the analysis of ONR in IR, and has filled in an important void in the study and treatment of T2D.
\end{abstract}

Keywords: Orphan nuclear receptors; Transcription factors; Type 2 Diabetes; Insulin resistance

\section{Introduction}

Orphan nuclear receptors (ONRs) are members of the nuclear receptor superfamily of transcriptional factors that are implicated in a number of metabolic processes including lipid and glucose metabolism and energy expenditure [1]. Unlike the steroid hormone receptors and other transcription factors of the nuclear receptor superfamily, the ligands for the ONRs are unknown and suggests that there is a host of other signalling pathways that are regulated by undiscovered ligands [2]. This may have wide-reaching implications in many disease states and processes. In particular, the ONRs play a critical role in glucose and lipid metabolism, and energy expenditure $[1,3,4]$ and thus, are currently under investigation for their role in metabolic disease. Accordingly, several ONRs have been examined for their roles in insulin resistance and type 2 diabetes. For example, the liver $\mathrm{X}$ receptor (now an adopted ONR due to the identification of a ligand) global knockout mouse model shows improved muscle, hepatic and adipose tissue insulin sensitivity [5]. Moreover, the PPARs (another class of adopted ONRs) have received much attention as potential pharmacological targets for combating obesity and diabetes due to their important role in cell metabolism (specifically lipid metabolism) regulation [6] and amelioration of insulin resistance in skeletal muscle and liver [7-9].

Although there have been a number of studies on the role of ONRs in insulin resistant mouse models, there is no information, to our knowledge, on the regulatory response of the ONRs in a progressive insulin-resistance skeletal muscle cell system. Accordingly, in this study we aimed to address the regulation of several ONRs in an insulinresistant mouse $\mathrm{C} 2 \mathrm{C} 12$ skeletal muscle. We identified that a number of the ONRs respond significantly during the progression of cellular insulin resistance and therefore could play a role in the aetiology of this disorder.

\section{Experimental}

Cell culture and the creation of an insulin-resistant skeletal muscle cell system

Skeletal muscle C2C12 cells were grown in Dulbecco's minimum essential medium (DMEM) supplemented with $10 \%(\mathrm{v} / \mathrm{v})$ heatinactivated foetal bovine serum (HI-FBS) in the presence of $1 \mathrm{mM}$ sodium pyruvate, $0.1 \mathrm{mM}$ non-essential amino acid and $2 \mathrm{mM}$ L-glutamine, $100 \mathrm{U} / \mathrm{ml}$ penicillin and $100 \mu \mathrm{g} / \mathrm{ml}$ streptomycin. The cells were maintained at $37^{\circ} \mathrm{C}$ in an incubator of $5 \%(\mathrm{v} / \mathrm{v}) \mathrm{CO}_{2}$ atmosphere. The cell culture medium was replaced every three days.

C2C12 myoblast cells were seeded into 6-well plates and allowed to grow until the cells reached $70 \%$ confluence before differentiation into skeletal muscle cells with $2 \%$ horse serum for 5 days. Prior to treatment with insulin, the cells were washed twice with PBS and pre-incubated for $4 \mathrm{hr}$ in medium containing $0.5 \%(\mathrm{v} / \mathrm{v}) \mathrm{HI}-\mathrm{FBS}$. The medium was then removed and replaced with fresh medium with $0.5 \%$ (v/v) HI-FCS in the presence of IL- 6 and incubated at $37^{\circ} \mathrm{C}$ in a humid atmosphere of air containing $5 \%(\mathrm{v} / \mathrm{v}) \mathrm{CO}_{2}$ for the requisite time. For the development of insulin-resistant skeletal muscle phenotype, $\mathrm{C} 2 \mathrm{C} 12$ cells were exposed to chronic insulin $(10 \mathrm{nM})$ treatments over the series of $0 \mathrm{~h}$, $0.5 \mathrm{~h}, 2 \mathrm{~h}, 4 \mathrm{~h}, 8 \mathrm{~h}, 24 \mathrm{~h}$, and $48 \mathrm{~h}$ (12). Media was refreshed every eight

${ }^{*}$ Corresponding author: Stephen Myers, School of Health Sciences, University of Tasmania, Australia, Tel: +61 36324 5459; E-mail: stephen.myers@utas.edu.au

Received October 26, 2015; Accepted November 18, 2015; Published November 24, 2015

Citation: Chew GS, Gawned M, Molina E, Myers SA (2015) Quantitative Analysis of Orphan Nuclear Receptors in Insulin-Resistant C2C12 Skeletal Muscle Cells. J Diabetes Metab 6: 626. doi:10.4172/2155-6156.1000626

Copyright: ( $) 2015$ Chew GS, et al. This is an open-access article distributed under the terms of the Creative Commons Attribution License, which permits unrestricted use, distribution, and reproduction in any medium, provided the original author and source are credited. 
hours to avoid depleting media components and insulin. For protein phosphorylation detection, $10 \mathrm{nM}$ insulin was added for $30 \mathrm{~min}$ before cell lysates harvest at each time point [10]. For control samples, fresh medium with $0.5 \%$ (v/v) HI-FCS, without insulin, was used. Following completion of the incubation period, the cells were harvested for RNA isolation and protein extract.

\section{Isolation of total cellular RNA}

Total cellular RNA was isolated from cells cultured in 6-well tissue culture plates using TRIzol Reagent $\left(\right.$ Ambion $\left.^{\circledR}\right)$ according to the manufacturer's instruction. Briefly, cells were first rinsed twice with PBS and then lysed on the addition of $1 \mathrm{ml}$ of Tri-Reagent. The homogenate was then incubated at room temperature for 5 min followed by vortexing in $100 \mu \mathrm{l}$ of chloroform. The RNA was extracted by centrifugation at $12,000 \mathrm{x}$ g for $15 \mathrm{~min}$ at $4^{\circ} \mathrm{C}$ followed by precipitation with isopropanol. The concentration and purity of the isolated RNA was determined by measuring the absorbance at $260 \mathrm{~nm}$ and $280 \mathrm{~nm}$ using NANODROP 2000 (Thermo Scientific ${ }^{\circledR}$ ).

\section{Synthesis of cDNA and Real-Time PCR}

Two $\mu$ g of total RNA was reverse transcribed into cDNA with the High Transcriptase cDNA kit (Life Technology ${ }^{\circledR}$ ). Quantitative RealTime PCR was carried out using SYBR' Green (Bioline ${ }^{\circledR}$ ) according to the manufacturer's instructions. The level of gene expression was then measured using Viia7 qPCR machine (Life Technologies ${ }^{\circledR}$ ). Specifically, $25 \mathrm{ng}$ of cDNA was added to $5 \mu$ of SYBR' Green RT-PCR reaction mix (Bioline $\left.{ }^{\circledR}\right), 10 \mathrm{mM}$ each of the forward primer and reverse primer $\left(\right.$ Geneworks ${ }^{\circledR}$ ) (Table 1), and $0.5 \mu \mathrm{l}$ of nuclease free water in a final volume of $10 \mu \mathrm{l}$. Quantitative Real-Time PCR was then performed on a ViiA7 qPCR machine (Life Technologies ${ }^{\mathbb{B}}$ ) using the following method: PCR reaction protocol consisted 40 cycles of denaturation at $95^{\circ} \mathrm{C}$ for $20 \mathrm{sec}$; annealing at $60^{\circ} \mathrm{C}$ for $30 \mathrm{sec}$, and an extension at $72^{\circ} \mathrm{C}$ for $30 \mathrm{sec}$. This was followed by the melt curve analysis which was carried out at $95^{\circ} \mathrm{C}$ for $1 \mathrm{~min}, 55^{\circ} \mathrm{C}$ for $1 \mathrm{~min}$ and 40 cycles of $70^{\circ} \mathrm{C}$ for $10 \mathrm{sec}$, increasing by $0.5^{\circ} \mathrm{C}$ each cycle. PCR products were normalized against the housekeeping gene, eukaryotic elongation factor 2 (Eef2).

\section{Western blot analysis}

Protein extracts used in Western blot analysis were extracted using RIPA buffer ${ }^{\circledR}\left(\right.$ Ambion $\left.^{\circledR}\right)$ containing Halt protease and phosphatase inhibitor cocktail (Thermo Fisher Scientific ${ }^{\mathbb{B}}$ ) according to the manufacturer's instructions. Protein samples $(20 \mu \mathrm{g})$ were used in SDS-PAGE in order to determine the levels of protein content for phosphorylated, Tyr30 AKT and total AKT, respectively. Subsequently, proteins were transferred to a polyvinylidene difluoride membrane $\left(\right.$ Milipore $\left.^{\circledR}\right)$ and incubated with blocking solution (1X PBS containing $5 \%(\mathrm{w} / \mathrm{v})$ skimmed milk powder and $0.1 \%(\mathrm{v} / \mathrm{v})$ Tween-20) for $1 \mathrm{~h}$ at room temperature with shaking. The membrane was washed three times for 10 min each in washing solution (1X PBS and $0.1 \%(\mathrm{v} / \mathrm{v})$ Tween-20) and incubated with primary antibodies (rabbit anti-mouse Tyr30 AKT, and total AKT), which was diluted $1 / 1000$ in $1 \mathrm{X}$ PBS containing $1 \%(\mathrm{w} / \mathrm{v})$ skimmed milk powder and $0.1 \%(\mathrm{v} / \mathrm{v})$ Tween-20, for $1 \mathrm{~h}$ at room temperature. The membrane was then washed and immersed in secondary antibody (peroxidase-conjugated goat antirabbit IgG) diluted $1 / 2000$ in $1 \mathrm{X}$ PBS containing $1 \%(\mathrm{w} / \mathrm{v})$ skimmed milk powder and $0.1 \%(\mathrm{v} / \mathrm{v})$ Tween-20. Detection of membrane-bound antigen-antibody complexes as immunoreactive signals was detected

\begin{tabular}{|c|c|c|c|c|c|c|c|}
\hline \multicolumn{8}{|c|}{ Time (mins) } \\
\hline \multicolumn{8}{|c|}{ NR 00.52482448} \\
\hline \multicolumn{8}{|c|}{ Relative Expression against EEF2 \pm SD } \\
\hline Coupt-f1 & $126.0 \pm 5.5$ & $85.8 \pm 0.90$ & $99.09 \pm 5.90$ & $88.07 \pm 2.26$ & $83.44 \pm 4.70$ & $20.57 \pm 2.90^{* * *}$ & $89.91 \pm 4.27$ \\
\hline Coup-tf2 & $564.12 \pm 17.89$ & $409.81 \pm 19.57$ & $597.64 \pm 8.57$ & $571.62 \pm 11.71$ & $434.74 \pm 45.03$ & $111.52 \pm 3.85^{\text {t*t }}$ & $293.08 \pm 16.33$ \\
\hline Ppar $\alpha$ & $1.28 \pm 0.066$ & $1.61 \pm 0.203$ & $1.45 \pm 0.070$ & $1.30 \pm 0.150$ & $1.56 \pm 0.110$ & $2.20 \pm 0.45$ & $0.855 \pm 0.03$ \\
\hline Ppar $\beta$ & $635.60 \pm 40.23$ & $498.06 \pm 40.11$ & $746.39 \pm 165.80$ & $683.01 \pm 32.40$ & $549.11 \pm 12.56$ & $1515.96 \pm 38.22^{4 * *}$ & $574.52 \pm 28.47$ \\
\hline Ppary & $43.31 \pm 3.80$ & $27.10 \pm 9.79$ & $44.61 \pm 2.78$ & $36.33 \pm 0.38$ & $26.04 \pm 1.57$ & $34.52 \pm 2.29$ & $33.61 \pm 2.45$ \\
\hline Nor-1 & $13.98 \pm 1.71$ & $18.20 \pm 0.83$ & $153.37 \pm 7.89^{*+*}$ & $22.63 \pm 1.50$ & $61.82 \pm 3.38$ & $487.34 \pm 14.40^{* * *}$ & $74.32 \pm 0.95$ \\
\hline Nurr1 & $5.83 \pm 0.53$ & $14.15 \pm 1.48$ & $67.63 \pm 2.60$ & $10.19 \pm 2.5$ & $21.0 \pm 2.38$ & $108.6 \pm 3.11^{* *}$ & $8.93 \pm 1.24$ \\
\hline Nur77 & $44.12 \pm 0.58$ & $574.41 \pm 68.73^{\star \star * *}$ & $1084.83 \pm 53.97^{* \star * *}$ & $26.08 \pm 0.17$ & $104.26 \pm 4.18$ & $504.54 \pm 8.01^{\text {tatk }}$ & $44.35 \pm 3.0$ \\
\hline Reverb $\alpha$ & $160.69 \pm 10.61$ & $155.23 \pm 3.35$ & $151.85 \pm 6.21$ & $154.14 \pm 1.95$ & $530.33 \pm 5.18^{2 * * t}$ & $1080.14 \pm 48.62^{+* *}$ & $141.07 \pm 6.21$ \\
\hline Reverb $\beta$ & $0.25 \pm 0.072$ & $0.17 \pm 0.04$ & $0.17 \pm 0.06$ & $0.20 \pm 0.11$ & $0.32 \pm 0.15$ & $0.50 \pm 0.20$ & $0.35 \pm 0.16$ \\
\hline $\operatorname{Rar} \alpha$ & $148.43 \pm 18.60$ & $125.63 \pm 15.35$ & $104.27 \pm 14.48$ & $164.10 \pm 16.14$ & $183.88 \pm 6.41$ & $203.49 \pm 3.80$ & $127.75 \pm 9.45$ \\
\hline $\operatorname{Rar} \beta$ & $4.40 \pm 0.18$ & $4.06 \pm 0.57$ & $3.96 \pm 0.15$ & $3.62 \pm 0.53$ & $8.05 \pm 0.59$ & $7.15 \pm 0.74$ & $8.8 \pm 0.82$ \\
\hline $\operatorname{Rar} Y$ & $16.39 \pm 2.5$ & $9.35 \pm 0.66$ & $12.31 \pm 1.74$ & $16.79 \pm 3.85$ & $14.13 \pm 1.30$ & $6.51 \pm 1.02^{*}$ & $17.90 \pm 0.32$ \\
\hline Err $\alpha$ & $132.65 \pm 5.62$ & $114.19 \pm 5.08$ & $111.96 \pm 14.25$ & $167.08 \pm 1.65$ & $193.07 \pm 4.78$ & $395.98 \pm 13.96^{* *}$ & $163.63 \pm 4.25$ \\
\hline $\operatorname{Err} \beta$ & $0.70 \pm 0.35$ & $0.38 \pm 0.10$ & $0.77 \pm 0.07$ & $0.92 \pm 0.01$ & $0.59 \pm 0.08$ & $0.76 \pm 0.14$ & $0.43 \pm 0.05$ \\
\hline $\operatorname{Lxr} a$ & $88.43 \pm 130.76$ & $84.88 \pm 16.73$ & $168.43 \pm 45.73$ & $87.37 \pm 20.62$ & $152.99 \pm 31.17$ & $232.36 \pm 15.76$ & $165.51 \pm 2.54$ \\
\hline $\operatorname{Lxr} \beta$ & $6.48 \pm 2.35$ & $6.37 \pm 1.22$ & $7.26 \pm 1.58$ & $7.26 \pm 0.15$ & $7.50 \pm 1.01$ & $12.06 \pm 1.29$ & $9.53 \pm 0.32$ \\
\hline $\operatorname{Rxr} \alpha$ & $631.83 \pm 40.54$ & $321.42 \pm 18.66^{* *}$ & $414.05 \pm 10.14$ & $432.84 \pm 19.63$ & $525.97 \pm 16.29$ & $497.06 \pm 36.49$ & $612.73 \pm 33.02$ \\
\hline$R \times r \beta$ & $50.97 \pm 7.01$ & $39.87 \pm 3.08$ & $39.28 \pm 1.73$ & $50.38 \pm 6.31$ & $85.94 \pm 0.50$ & $57.64 \pm 12.24$ & $63.78 \pm 3.84$ \\
\hline$R x r y$ & $2.21 \pm 2.31$ & $1.57 \pm 1.18$ & $1.62 \pm 0.99$ & $1.59 \pm 0.46$ & $3.47 \pm 3.6$ & $4.57 \pm 1.91$ & $3.28 \pm 0.30$ \\
\hline Ror $\alpha$ & $684.70 \pm 77.43$ & $386.92 \pm 62.60$ & $660.44 \pm 59.14$ & $457.74 \pm 39.44$ & $927.52 \pm 109.80$ & $1900.72 \pm 242.43^{\text {tw* }}$ & $852.56 \pm 101.46$ \\
\hline $\operatorname{Ror} y$ & $11.81 \pm 2.25$ & $8.70 \pm 0.44$ & $12.44 \pm 4.38$ & $6.62 \pm 1.06$ & $7.80 \pm 2.09$ & $3.54 \pm 0.53^{*}$ & $24.41 \pm 6.19$ \\
\hline Hnf $4 \alpha$ & $2.19 \pm 0.66$ & $1.84 \pm 0.73$ & $2.36 \pm 0.39$ & $1.61 \pm 0.29$ & $1.45 \pm 0.32$ & $1.41 \pm 0.24$ & $2.15 \pm 0.58$ \\
\hline Hnf4 Y & $33.79 \pm 6.41$ & $23.00 \pm 1.40$ & $37.19 \pm 7.05$ & $46.10 \pm 3.02$ & $27.27 \pm 2.56$ & $16.15 \pm 2.14$ & $34.48 \pm 4.68$ \\
\hline Ear 2 & $219.86 \pm 42.03$ & $186.17 \pm 5.74$ & $251.13 \pm 16.12$ & $250.40 \pm 2.59$ & $205.03 \pm 7.82$ & $77.06 \pm 1.57$ & $225.35 \pm 15.61$ \\
\hline Shp & $0.16 \pm 0.06$ & $0.11 \pm 0.01$ & $0.23 \pm 0.09$ & $0.20 \pm 0.12$ & $0.06 \pm 0.02$ & $0.28 \pm 0.03$ & $0.29 \pm 0.05$ \\
\hline
\end{tabular}

Table 1: Quantitative real-time PCR of ONRs in C2C12 cells treated with $10 \mathrm{nM}$ insulin over $48 \mathrm{~h}$. 
using chemiluminiscence SuperSignal West Pico Substrate (Pierce ${ }^{\circledR}$ ) and visualised using UVITEC Alliance digital imaging system (Thermo Fisher Scientific $\left.{ }^{\circledR}\right)$.

\section{Statistics}

Statistical analyses were performed using Microsoft Excel software and all data were analyzed using a Student's unpaired t-test \pm SD, where ${ }^{\star} p \leq 0.05,{ }^{* *} p \leq 0.01$, and ${ }^{* *} p \leq 0.001$.

\section{Results}

The effects of insulin on the phosphorylation of AKT and the production of insulin resistance model in $\mathrm{C} 2 \mathrm{C} 12$ skeletal muscle cells

In order to create an insulin-resistant skeletal muscle cell line, we stimulated C2C12 cells with $10 \mathrm{nM}$ of insulin over $0,0.5,2,4,8,24$, and $48 \mathrm{~h}$ replacing the media and insulin every $8 \mathrm{~h}$. This method has been successfully used in a number of studies to create insulin-resistant C2C12 cells $[11,12]$. Total cellular protein was extracted using RIPA buffer and $20 \mu \mathrm{g}$ of total cellular protein was subjected to SDS-PAGE, and subsequently blotted onto Immobilon-PVDF membrane. The relative levels of pAKT was detected relative to total AKT (Figure 1). Following $30 \mathrm{~min}$ of insulin treatment there was an increase in the levels of pAKT that were further increased at 2 and $4 \mathrm{~h}$ of insulin treatment. The level of phosphorylation then rapidly decreased at $8 \mathrm{~h}$ and became almost undetectable at 24 and $48 \mathrm{~h}$ (Figure 1). Overall, there was no change in total AKT protein observed, suggesting that the C2C12 cells had obtained the insulin-resultant phenotype.

\section{The effects of insulin on the mRNA expression of orphan nuclear receptors in an insulin-resistant $\mathrm{C} 2 \mathrm{C} 12$ skeletal muscle cell line}

To determine if any of the ONRs responded to increases in insulinresistance, we analysed a progressively insulin-resistant C2C12 skeletal muscle cell line. We analysed several ONRs by quantitative real-time PCR and observed several significant changes in a number of the ONRs as the cells became increasingly insulin resistant (Table 1). Of these, Coup-tf1 and Coup-tf2, Ror $\gamma$ and Rar $\gamma$ were significantly decreased at 24 h of insulin treatment while Ppar $\beta$, Ppar $\gamma$ Nor-1, Nurr1, Nur77, Reverb $\alpha$, Rar $\alpha$, Rar $\beta$, Err $\alpha$, Ror $\alpha$ and $M r$ were all significantly increased at $24 \mathrm{~h}$ of insulin treatment (Table 1). Other significant changes were observed for Nor-1 (increased at $2 \mathrm{~h}$ ), Nur77 (increased at 0.5 and $2 \mathrm{~h}$ ), Reverb $\alpha$ (increased at $8 \mathrm{~h}$ ), $\operatorname{Rxr} \alpha$ (decreased at $0.5 \mathrm{~h}$ ), and $V d r$ (increased at $8 \mathrm{~h}$ ) (Table 1). A representative figure (Figure 2) shows in graphical form a number of the orphan nuclear receptors that

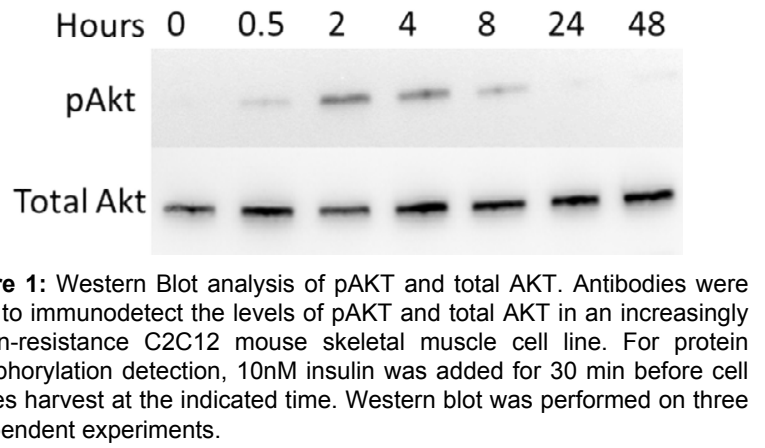

$\mathrm{J}$ Diabetes Metab

ISSN: 2155-6156 JDM, an open access journal were significantly changes in the presence of $10 \mathrm{nM}$ insulin and the acquisition of the insulin-resistant skeletal muscle phenotype.

\section{Discussion}

This study identified the regulatory response of several ONRs in response to skeletal muscle cells becoming increasingly resistant to insulin over time. We identified that $10 \mathrm{nM}$ of insulin was sufficient to induce the phosphorylation of AKT after 30 min of treatment and that this phosphorylation was transient and rapidly declined post $2 \mathrm{~h}$. This is supported by several studies that demonstrated that insulin resistant could be measured by the amount of $\mathrm{pAKT}$ relative to total AKT protein over time with chronic insulin treatment [12-15]. Thus, reduced pAKT levels are consistent with an increase in insulin resistance. Given that the ONR regulate genes are involved in many cellular mechanism, including metabolism, and have been linked to metabolic conditions including type 2 diabetes [16], it is reasonable to conclude that they may also be implicated in insulin resistance.

A number of ONRs were significantly regulated on the acquisition of the insulin resistant phenotype in $\mathrm{C} 2 \mathrm{C} 12$ skeletal muscle cells in including Coup-tf1, Coup-tf2, Ppar $\beta$, Nor-1, Nurr1, Nur77, Reverb $\alpha$, and Ror $\alpha$ (Table 1). These ONRs have various roles in the context of metabolism and specifically in relation to carbohydrate and lipid metabolism and energy expenditure [1], and are discussed below.

Coup-tf1 and Coup-tf2 were both significantly down-regulated at 24 $\mathrm{h}$ of insulin treatment in the insulin-resistant skeletal muscle cell line. This is consistent with previous studies that identified that exogenous insulin reduced the levels of Coup-tf2 mRNA and protein in INS-1 $\beta$-cell lines and pancreatic islet $\beta$-cells [17]. Moreover, these authors found that $\mathrm{C} 57 \mathrm{BL} / 6 \mathrm{~J}$ mouse hepatocytes that were cultured with 10 $\mathrm{nM}$ of insulin over $24 \mathrm{~h}$ had reduced levels of Coup-tf2. However, it is difficult to determine whether these effects in both our studies and the studies by Perilhou et al. [17] were due to insulin directly or indirectly targeting Coup-tf2 expression or due to the cells (skeletal muscle and hepatocytes) undergoing changes in insulin resistance. From this study and others [12,18], chronic insulin treatment of $10 \mathrm{nM}$ over $24 \mathrm{~h}$ is enough to reduce levels of pAkt and is indicative of the cells acquiring an insulin-resistant phenotype. Coup-tf2 overexpression in $\mathrm{C} 2 \mathrm{C} 12$ skeletal muscle cells also increased Pgc1 $\alpha$ and Glut4 mRNA and protein and suggest that these cells may have improved insulin sensitivity and glucose uptake [19]. In fact, in mice that had a pancreatic $\beta$-cell specific Coup-tf2 deficiency these animals had altered insulin secretion that was associated with peripheral insulin resistance and impaired glucose sensitivity [20].

$P p a r \beta$ was significantly up-regulated at $24 \mathrm{~h}$ of insulin treatment in contrast to the other family members Ppar $\alpha$ and Ppary who showed no response to the acquisition of the insulin resistant phenotype. Ppar $\beta$ plays an important role in controlling fatty acid metabolism in skeletal muscle cells [21]. Previous studies have shown that $P p a r \beta$ enhances insulin sensitivity [22] and prevents lipid-induced endoplasmic reticulum stress, and thus insulin resistance, in mouse and human skeletal muscle [23]. Accordingly, the increase in Ppar $\beta$ in the progressively insulin-resistant skeletal muscle cells may be a compensatory action to regulate insulin sensitivity. Actually, Ppar $\beta$ activation prevented palmitate-induced inflammation and insulin resistance in skeletal muscle cells by increasing fatty acid oxidation [23].

The NR4A family of ONRs (Nor-1, Nurr1 and Nur77) were all induced at various times as the skeletal muscle cells became progressively 


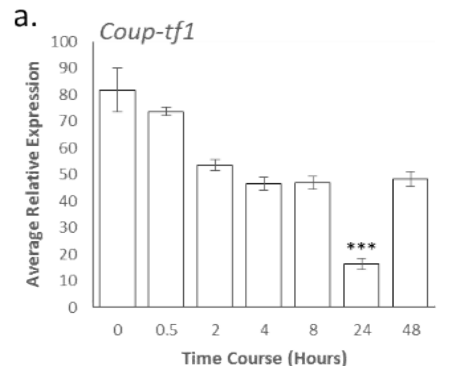

e.

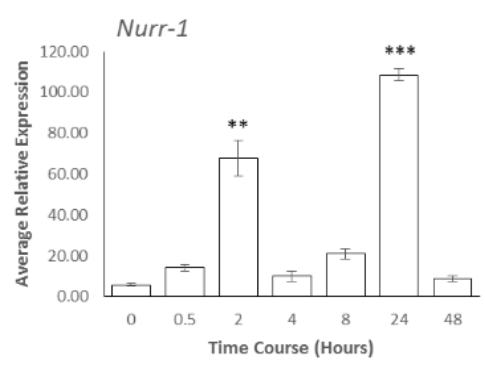

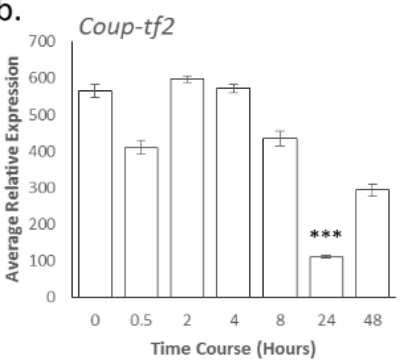

f.

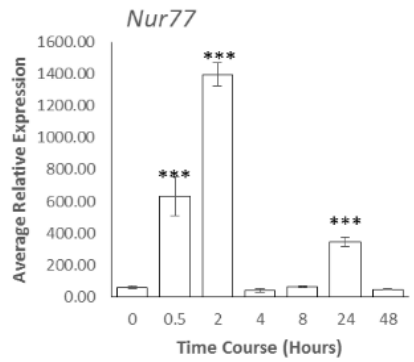

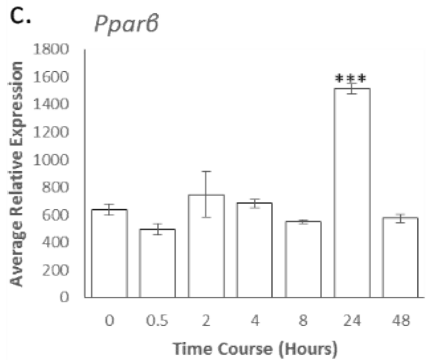

g.

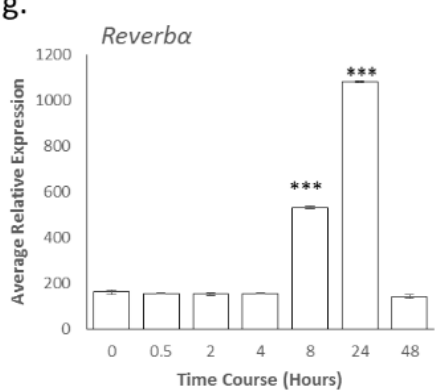

d.

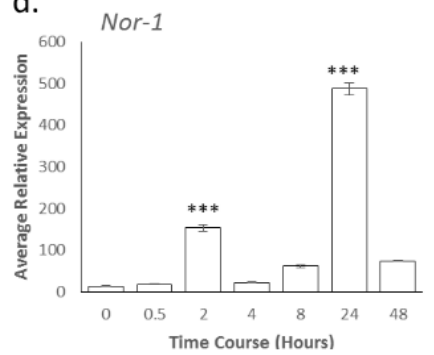

h.

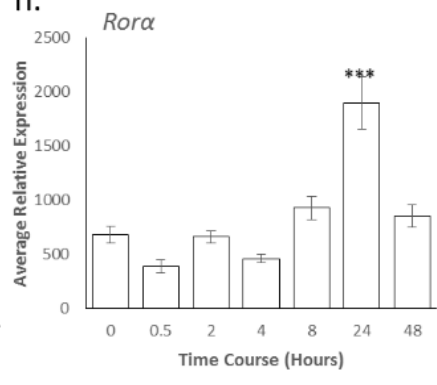

Figure 2: Representative graphs of changes in ONRs due to increasing insulin resistance in skeletal muscle. A-b: Coup-tf1 and Coup-tf2, C: Ppar $\beta$, D-F: Nor-1, Nurr-1 and Nur77, G: Reverba, and H: Rora.

insulin resistant. There is little information available on the role of the NR4As in insulin resistance however, studies by Fu et al. [24] found that Nur77 and Nor-1 were induced with $10 \mathrm{nM}$ insulin in 3T3-L1 adipocytes cells at $1 \mathrm{~h}$ and $2 \mathrm{~h}$, respectively. This is in collaboration to our studies were we show both Nur77 and Nor-1 induced by $10 \mathrm{nM}$ insulin at $30 \mathrm{~min}$ and $2 \mathrm{~h}$ (Nur77) and $2 \mathrm{~h}($ Nor-1). We also observed significant induction of Nurr 1 during this $2 \mathrm{~h}$ time period, however in addition, we found that all three NR4As were significantly reduced to basal levels over 4 and $8 \mathrm{~h}$, before being up-regulated at $24 \mathrm{~h}$ of insulin treatment. The increase at $24 \mathrm{~h}$ for all three NR4As is suggestive of the acquisition of the insulin-resistant phenotype due to the fact that the NR4As respond within $2 \mathrm{~h}$ of insulin treatment before falling to basal levels [25]. As C2C12 cells become insulin resistant, they undergo oxidative stress and impaired gene expression of the insulin signaling pathway [26]. It has been revealed that the NR4As are also induced under a host of functions including changes in metabolism, insulin sensitivity, and oxidative stress conditions [27].

Reverb $\alpha$ was significantly induced at 8 and $24 \mathrm{~h}$ of insulin treatment and the acquisition of the insulin-resistant phenotype. This ONR plays a crucial role in the regulation of circadian rhythms and including those associated with food intake [28]. Mice that lack Reverba display changes in their daily energy homeostasis and predisposition to dietinduced obesity [29]. Moreover, the ablation of Reverba by siRNA in islet cells and MIN-6 pancreatic cells impaired glucose-induced insulin secretion, decreased genes implicated in lipid metabolism, and impaired $\beta$-cell function [30]. It was suggested by these authors that Reverba may therefore play a critical role in the daily dynamics of insulin secretion. Equally, Err $\alpha$ was significantly upregulated at $24 \mathrm{~h}$ following insulin treatment. Similar to Reverb $\alpha$ there is little information on the role of this ONR in insulin resistance. The ERRs ( $\alpha$ and $\beta$ ) are involved in transcriptional control of cellular energy metabolism and may also be implicated in the aetiology of metabolic disorders, such as type 2 diabetes and metabolic syndrome [31].

These studies show that some of the ONRs are sensitive to changes in the skeletal muscle phenotype resulting from insulin-induced, skeletal muscle insulin-resistance and therefore may be amendable to therapeutic intervention to treat or better manage insulin resistance and disease progression. Further studies are required to delineate the role of these ONRs in insulin resistance progression and to establish a platform for drug therapy in skeletal muscle-associated insulin resistance and subsequence disease states.

\section{References}

1. Myers SA, Wang SC, Muscat GE (2006) The Chicken Ovalbumin Upstream Promoter-Transcription Factors Modulate Genes and Pathways Involved in Skeletal Muscle Cell Metabolism. J Biol Chem 281: 24149-24160.

2. Evans RM, Mangelsdorf DJ (2014) Nuclear Receptors, RXR, and the Big Bang Cell 157: 255-266.

3. Baranowski M, Zabielski P, Blachnio-Zabielska AU, Harasim E, Chabowski A, et al. (2014) Insulin-sensitizing effect of LXR agonist T0901317 in high-fat fed rats is associated with restored muscle GLUT4 expression and insulinstimulated AS160 phosphorylation. Cell Physiol Biochem 33: 1047-1057.

4. Vacca M, Degirolamo C, Mariani-Costantini R, Palasciano G, Moschetta A (2011) Lipid-sensing nuclear receptors in the pathophysiology and treatment of the metabolic syndrome. Wiley Interdiscip Rev Syst Biol Med 3: 562-587.

5. Beaven SW, Matveyenko A, Wroblewski K, Chao L, Wilpitz D, et al. (2013) Reciprocal regulation of hepatic and adipose lipogenesis by liver $X$ receptors in obesity and insulin resistance. Cell Metab 18: 106-117.

6. Shi $Y$ (2007) Orphan nuclear receptors in drug discovery. See comment in PubMed Commons below Drug Discov Today 12: 440-445.

7. Bonet ML, Ribot J, Palou A (2012) Lipid metabolism in mammalian tissues and its control by retinoic acid. Biochim Biophys Acta 1821: 177-189.

8. Kim YD, Kim YH, Cho YM, Kim DK, Ahn SW, et al. (2012) Metformin ameliorates IL-6-induced hepatic insulin resistance via induction of orphan nuclear receptor small heterodimer partner (SHP) in mouse models. Diabetologia 55: 1482 1494.

9. Wang SC, Muscat GE (2013) Nuclear receptors and epigenetic signaling: nove regulators of glycogen metabolism in skeletal muscle. IUBMB Life 65: 657-664.

10. Yang M, Wei D, Mo C, Zhang J, Wang X, et al. (2013) Saturated fatty acid palmitate-induced insulin resistance is accompanied with myotube loss and 
Citation: Chew GS, Gawned M, Molina E, Myers SA (2015) Quantitative Analysis of Orphan Nuclear Receptors in Insulin-Resistant C2C12 Skeletal Muscle Cells. J Diabetes Metab 6: 626. doi:10.4172/2155-6156.1000626

Page 5 of 5

the impaired expression of health benefit myokine genes in $\mathrm{C} 2 \mathrm{C} 12$ myotubes. Lipids Health Dis 12: 104.

11. Chavez JA, Summers SA (2003) Characterizing the effects of saturated fatty acids on insulin signaling and ceramide and diacylglycerol accumulation in 3T3L1 adipocytes and C2C12 myotubes. Arch Biochem Biophys 419: 101-109.

12. Kumar N, Dey CS (2003) Development of insulin resistance and reversal by thiazolidinediones in C2C12 skeletal muscle cells. Biochem Pharmacol 65: 249-257.

13. Cantley LC (2002) The phosphoinositide 3-kinase pathway. Science 296 1655-1657.

14. Houstis N, Rosen ED, Lander ES (2006) Reactive oxygen species have a causal role in multiple forms of insulin resistance. Nature 440: 944-948.

15. Myers SA, Nield A, Chew GS, Myers MA (2013) The zinc transporter, SIc39a7 (Zip7) is implicated in glycaemic control in skeletal muscle cells. PLoS One 8: e79316.

16. Tontonoz P, Hu E, Spiegelman BM (1994) Stimulation of adipogenesis in fibroblasts by PPAR gamma 2, a lipid-activated transcription factor. Cell 79 : 1147-1156.

17. Perilhou A, Tourrel-Cuzin C, Kharroubi I, Henique C, Fauveau V, et al. (2008) The transcription factor COUP-TFII is negatively regulated by insulin and glucose via Foxo1- and ChREBP-controlled pathways. Mol Cell Biol 28: 65686579.

18. Berdichevsky A, Guarente L, Bose A (2010) Acute oxidative stress can reverse insulin resistance by inactivation of cytoplasmic JNK. J Biol Chem 285: 21581 21589.

19. Crowther LM, Wang SC, Eriksson NA, Myers SA, Murray LA, et al. (2011) Chicken ovalbumin upstream promoter-transcription factor II regulates nuclear receptor, myogenic, and metabolic gene expression in skeletal muscle cells. Physiol Genomics 43: 213-227.

20. Bardoux P, Zhang P, Flamez D, Perilhou A, Lavin TA, et al. (2005) Essentia role of chicken ovalbumin upstream promoter-transcription factor II in insulin secretion and insulin sensitivity revealed by conditional gene knockout. Diabetes 54: 1357-1363.
21. Coll T, Rodrïguez-Calvo $R$, Barroso $E$, Serrano L, Eyre E, et al. (2009) Peroxisome proliferator-activated receptor (PPAR) beta/delta: a new potentia therapeutic target for the treatment of metabolic syndrome. Curr Mol Pharmaco 2: 46-55.

22. Wang YX, Lee CH, Tiep S, Yu RT, Ham J, et al. (2003) Peroxisome-proliferator activated receptor delta activates fat metabolism to prevent obesity. Cell 113: 159-170.

23. Salvadó L, Barroso E, Gómez-Foix AM, Palomer X, Michalik L, et al. (2014) PPARbeta/delta prevents endoplasmic reticulum stress-associated inflammation and insulin resistance in skeletal muscle cells through an AMPKdependent mechanism. Diabetologia 57: 2126-2135.

24. Fu Y, Luo L, Luo N, Zhu X, Garvey WT (2007) NR4A orphan nuclear receptors modulate insulin action and the glucose transport system: potential role in insulin resistance. See comment in PubMed Commons below J Biol Chem 282: 31525-31533.

25. Gao M, Bu L, Ma Y, Liu D (2013) Concurrent activation of liver X receptor and peroxisome proliferator-activated receptor alpha exacerbates hepatic steatosis in high fat diet-induced obese mice. PLoS One 8: e65641.

26. Yu R, Luo J, Yu R (2015) Docosahexaenoic acid attenuated palmitate-induced insulin resistance in C2C12 cells. Zhonghua Yi Xue Za Zhi 95: 226-230.

27. Ranhotra HS (2015) The NR4A orphan nuclear receptors: mediators in metabolism and diseases. J Recept Signal Transduct Res 35: 184-188.

28. Duez H, Staels B (2009) Rev-erb-alpha: an integrator of circadian rhythms and metabolism. J Appl Physiol (1985) 107: 1972-1980.

29. Delezie J, Dumont S, Dardente H, Oudart H, Gréchez-Cassiau A, et al (2012) The nuclear receptor REV-ERBa is required for the daily balance of carbohydrate and lipid metabolism. FASEB J 26: 3321-3335

30. Vieira E, Marroquí L, Batista TM, Caballero-Garrido E, Carneiro EM, et al. (2012) The clock gene Rev-erba regulates pancreatic $\beta$-cell function: modulation by leptin and high-fat diet. Endocrinology 153: 592-601.

31. Audet-Walsh E, Giguére V (2015) The multiple universes of estrogen-related receptor $\alpha$ and $y$ in metabolic control and related diseases. Acta Pharmaco $\operatorname{Sin} 36$ : 51-61. 